\title{
Results From Mozambique's 2014 Report Card on Physical Activity for Children and Youth
}

\author{
António Prista, Salazar Picardo, Edmundo Ribeiro, Joel Libombo, and Timoteo Daca
}

\begin{abstract}
Background: This paper describes the procedures and development of the first Mozambican Report Card on Physical Activity in Children and Adolescents. Methods: Comprehensive searches for data related to indicators of physical activity (PA) were completed by a committee of physical activity and sports specialists. Grades were assigned to each indicator consistent with the process and methodology outlined by the Active Healthy Kids Canada Report Card model. Results: Seven indicators of PA were graded. The following grades were assigned: Overall Physical Activity Levels, B; Organized Sport Participation, F; Active Play, C; Active Transportation, B; Schools, C; Community and the Built Environment, F; and Government, C. Sedentary Behaviors and Family and Peers were not graded due to the lack of available information. Conclusions: PA behaviors of children and young people of Mozambique are positively influenced by the rural environment and are largely related to subsistence activities and outdoor play, and absence of motorized transport. In turn, urban areas are declining in active habits and opportunities due largely to rapid urbanization and lack of planning that favors active transport and play.
\end{abstract}

Keywords: advocacy, policy, health communication, child health, knowledge translation

Mozambique, located in Southeast Africa, is bordered by the Indian Ocean, Tanzania, Malawi, Zambia, Zimbabwe, Swaziland, and South Africa. The total population was estimated at $\sim 25$ million in 2012 in a surface area of about $800,000 \mathrm{~km}^{2}$. The Mozambican $\mathrm{GDP} /$ per capita is $\$ 510^{1}$ and the Human Development Index is 0.327 , indicative of a country of low human development. ${ }^{2}$ Life expectancy is 50.4 and 54.5 years for men and women, respectively, ${ }^{3}$ and child mortality is $84 / 1000$ births. ${ }^{4}$ Literacy is $56 \%$. About $31 \%$ of the population lives in urban areas ${ }^{5}$ but $55 \%$ of the population lives in conditions of poverty. ${ }^{1}$ Domestic agriculture, fishing and forestry comprise $73 \%$ of economic activity while industry comprises only $4 \%$.

Living in a nonindustrialized country, Mozambican children and adolescents have historically been very active. ${ }^{6}$ Subsistence activities and active outdoor games contribute to relatively high energy expenditure among youth in both rural and urban areas compared with peers in the developed world. ${ }^{7}$ However, the last 2 decades have seen growth of urbanization associated with modern technology which have contributed to an increase in sedentary habits not observed before. The changed behaviors have coincided with an increase in the prevalence of cardiovascular risk factors in Mozambique. ${ }^{8}$ An increase in noncommunicable diseases may have different consequences, as Mozambique and many other subSaharan countries continue to have a high prevalence of transmissible diseases. ${ }^{9}$

It is important to evaluate the state of physical activity (PA) in Mozambique to develop a clear understanding of the problems related to physical inactivity, to monitor national trends, and to

Prista (corresponding author: aprista1@gmail.com), Ribeiro, Libombo, and Daca are with the Faculdade de Educação Física e Desporto, Universidade Pedagógica, Maputo, Moçambique. Prista, Ribeiro, and Daca are also with the Centro de Investigação e Desenvolvimento em Desporto e Actividade Física, Universidade Pedagógica, Maputo, Moçambique. Picardo is with the Instituto Nacional de Educação, MINED, Moçambique. plan effective interventions in the future. Robust surveillance data for Mozambique that would address these needs are lacking. The Active Healthy Kids Canada Report Card offers a model for gathering and consolidating high quality and representative data that already exist and for presenting the data in a format that is useable by researchers, policy makers, and practitioners. ${ }^{10} \mathrm{~A}$ report card on physical activity has never been attempted in Mozambique. Given the relevance of PA to the health of Mozambican children, particularly given the increase in sedentary behaviors, a systematic evaluation of the factors that affect physical activity behaviors in Mozambican children and young people is essential and can be useful. The purpose of this article is to describe the procedures and results of the first Mozambican Report Card for Physical Activity in Children and Adolescents.

\section{Methods}

The Research Group for Physical Activity and Health (NIAFS) located in the Research Center for Sports and Physical Activity (CIDAF) within the Universidade Pedagógica of Mozambique developed the Mozambique 2014 Report Card. An 8-member committee was established to prepare the Report Card. The team included researchers, post graduate students and senior staff members from the Ministry of Education, the Ministry of Sport and NonGovernment Organizations (NGO) in the field of sport and physical activity; all were professionals actively involved with PA and sport.

The Mozambique Report Card followed the procedures developed by Active Healthy Kids Canada. ${ }^{10}$ The initial phase focused data collection and involved 5 committee members. Searches were made of available databases, websites and official reports, and direct contact was made with governmental institutions and NGOs.

Due to a general lack of information available, a questionnaire based on the indicators of PA was developed and distributed among the research group members. On the basis of the few documents available and responses to the questionnaires, an evaluation table 
was drafted and distributed to all members for final comments and decision. Grades were assigned to each PA indicator based on estimates of the proportion of children and adolescents that were meeting a specified benchmark or guideline.

\section{Results}

The 2014 Mozambican Report Card on Physical Activity in Children and Adolescents includes nine indicators of PA suggested in the Canada model: Overall Physical Activity Levels, Organized Sport Participation, Active Play, Active Transportation, Sedentary Behaviors, Family and Peers, School, Community and the Built Environment, and Government. The grades assigned to each indicator are summarized in Table 1 and the front cover illustrated in Figure 1.

\section{Discussion}

Allowing for limitations related to the lack of objective data, it was clear that PA in Mozambique is positively influenced by the rural environment. However, rapid urban growth, much of which is unplanned, had shifted the population to urban centers and a more sedentary lifestyle.

The gap between urban and rural populations in Mozambique is extreme. Housing in rural areas is marginal with no electricity and piped water. People work in traditional, subsistence (nonmechanical) agriculture, and must walk daily to get water. Only $2.7 \%$ of the houses in Mozambique have piped water pipe in the house, and only $20 \%$ have electricity, almost all of which are in urban areas. ${ }^{11}$ As a consequence, the rural population expends considerable energy in daily chores, walking, carrying water and subsistence agriculture. Children and adolescents have a role in the daily household chores and agriculture. Children spend their free time in active outdoor games as since there is no TV and video games in rural areas. ${ }^{12,13}$ In contrast, the urban population, even in unprivileged and marginal areas, has electricity and piped water at home as well as access to motorized transport.

\section{Overall Physical Activity Levels}

Overall Physical Activity Level was assigned a B. PA levels have traditionally and historically been very high among children and adolescents in rural and urban areas of the country. ${ }^{12,14}$ Recent available data showed that in excess of $60 \%$ of rural children and

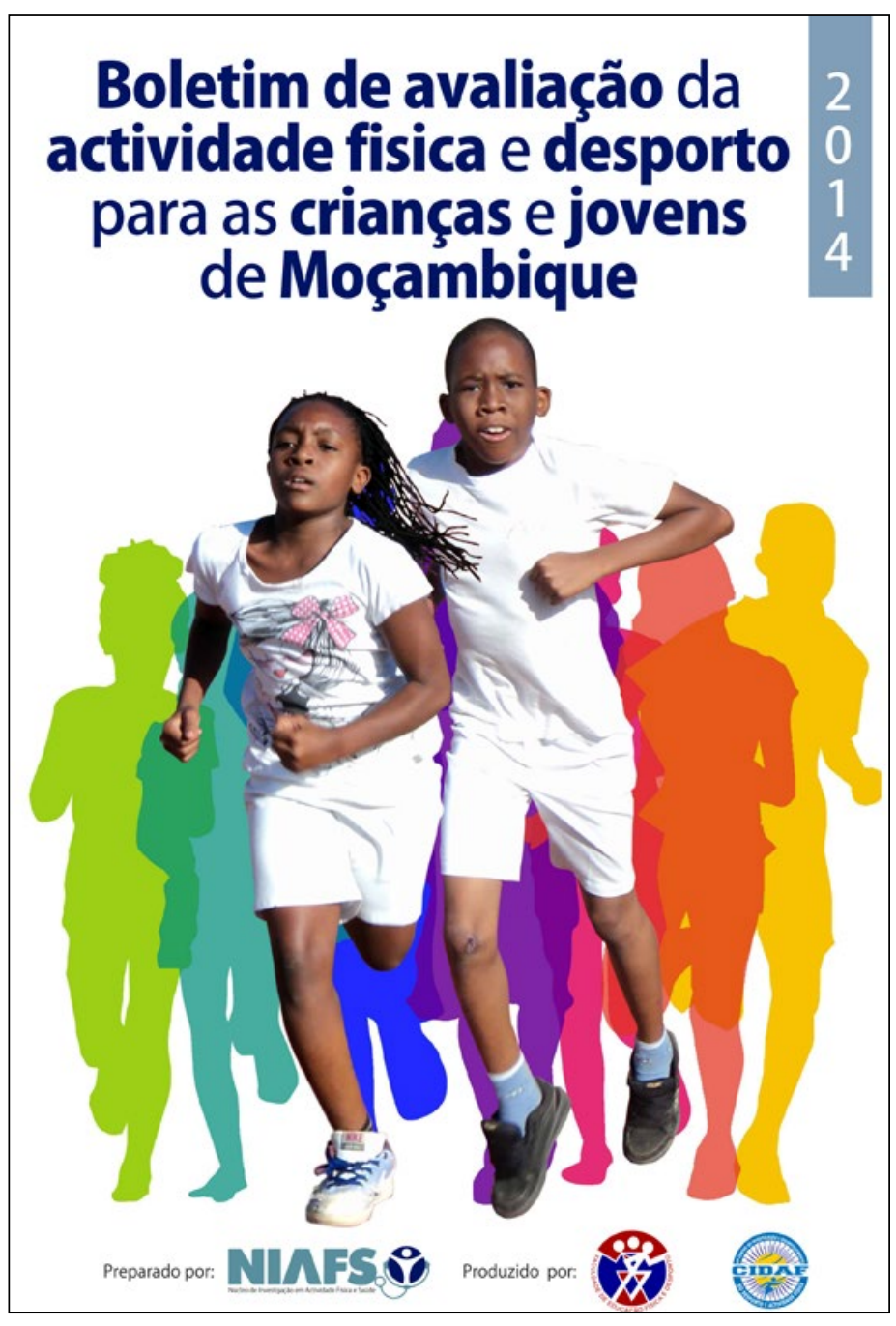

Figure 1 - Front cover of Mozambique 2014 Report Card.

adolescents walked more than 1 hour per day. ${ }^{15}$ Children from rural and peri-urban areas were also quite active in subsistence activities, such as pounding grain and carrying water, ${ }^{16}$ and often walked relatively long distances to school and/or water sources. In contrast, the percentage of children and adolescents in urban areas who walked

Table 1 Summary of Grades From the Mozambique Report Card

\begin{tabular}{lc}
\hline Indicator & Grades \\
\hline Overall Physical Activity Levels & $\mathrm{B}$ \\
Organized Sport Participation & $\mathrm{F}$ \\
Active Play & $\mathrm{C}$ \\
Active Transportation & $\mathrm{B}$ \\
Sedentary Behaviors & $\mathrm{INC}$ \\
Family and Peers & $\mathrm{INC}$ \\
School & $\mathrm{C}$ \\
Community and the built environment & $\mathrm{F}$ \\
Government & $\mathrm{C}$ \\
\hline
\end{tabular}

Note. The grade for each indicator is based on the percentage of children and youth meeting a defined benchmark: $A$ is $81 \%-100 \%$; $B$ is $61 \%-80 \%$; $C$ is $41 \%-60 \%, D$ is $21 \%-40 \% ; F$ is $0 \%-20 \%$; INC is Incomplete data. 
more than 1 hour per day was only $32 \%, 15$ and the decline in time spent walking in urban areas has been in progress for the past 20 years. ${ }^{17} \mathrm{~A}$ grade of $\mathrm{B}$ was, therefore, assigned to 'Overall Physical Activity Levels' considering that the majority of the population in Mozambique was still rural and most rural children and adolescents were quite physically active.

\section{Organized Sport Participation}

Organized sport and participation was assigned an F. Participation at the club level was very limited for the entire population including children and adolescents. Access to sport clubs was also extremely limited. Although there were no official statistics, children and youth who participated in sports events hosted by formal sports groups were manifestly scarce. Moreover, basic information on sports clubs, athletes and participation were not available and highlighted a significant area for future research.

\section{Active Play and Leisure}

Based on available literature related to PA and fitness of Mozambican school-aged children, increasing access to technology is beginning to reduce active outdoor play but has not yet replaced its predominance. ${ }^{17}$ Practice of so-called "traditional games" has decreased in the urban areas, but has been encouraged by a regular National Competition. ${ }^{18} \mathrm{~A}$ study evaluating unpublished data for rural and urban areas in several years spanning 1992-2012 estimated activity behaviors in school children and youth of both sexes aged 6-17 years using a validated questionnaires for this population. ${ }^{12}$ The prevalence of regular outdoor play was over $80 \%$ in rural areas, but decline from $67 \%$ to $57 \%$ among school youth in urban areas over the past 20 years. ${ }^{19}$ No information was available for preschool children. Based on this limited data which suggested a relatively high level of Active Play in rural areas but a lower level in urban areas, a grade of $\mathrm{C}$ was assigned.

\section{Active Transport}

A recent study of 2018 urban school children and adolescents showed that $52 \%$ walked to school (unpublished). The study was conducted in Maputo, the capital city, which is quite different from other cities in terms of size and infrastructure, including public transport. The majority of the Mozambique population (70\%) resides in rural area where there no public or private transportation is available; walking is the main means of transport across the age span. A grade of B was thus assigned to Active Transport.

\section{Sedentary Behavior}

Two available studies ${ }^{15,20}$ suggested that more than $60 \%$ of urban children watch TV for more than 1 hour per day compared with only $8 \%$ among rural children. The use of new social media, such as Facebook, has increased in cities, while mobile phone use has increased in rural areas. However, nationally representative data are lacking to inform this indicator. A grade of Incomplete was assigned.

\section{Family and Peers}

No data were available to inform this indicator. A grade of incomplete was assigned.

\section{School}

According to the Ministry of Education, physical education (PE) is mandatory from first through 12 th grades. ${ }^{21} \mathrm{PE}$ classes are taught by the classroom (general) teacher in the 1 st through 5 th grades and by PE specialists from the 6th grade on. ${ }^{22}$ According to the Ministry of Education Report, PE is mandatory twice a week; however, the 2 classes are often combined in a single day. Nevertheless, resources are very limited and the quality of the classes is low. Although PE is mandatory for all students, in practice there high percentage of children and adolescents does not participate in the classes.

The possibility of practicing sport is high in secondary schools but low in primary schools in which the majority of students are enrolled. In rural areas, school grounds (large open spaces) are very favorable for PA, particularly outdoor games. Although organized activities are fewer, rural children and adolescents play spontaneously.

Although PE programs ${ }^{21,22}$ include sport-specifically, basketball, handball, soccer, volleyball, and track and field athletics, and official school policy favors participation in sport for all students, ${ }^{23}$ most schools do not have sports facilities and equipment. The report card committee estimated that the percentage of schools with some sports facilities was less than $20 \%$. Given the overall circumstances, a grade of $\mathrm{C}$ was assigned for the School indicator.

\section{Community and the Built Environment}

The practice of PA is primarily related to subsistence activities, particularly in rural areas of the country. ${ }^{19}$ However, urbanization is occurring rapidly with an associated decline in subsistence PA in the developing cities. ${ }^{23}$ Although urban children and adolescents are spending less time in subsistence activities, sport and recreational facilities are not being built and there is no action to promote more facilities; in some instances, existing facilities have disappeared. ${ }^{17}$ In fact, the number of sports fields and recreational areas available in cities has declined to make way for new buildings and urban expansion. Public areas have also been reduced in size so that opportunities for active play have been further limited in cities.

\section{Policy}

There are several government laws and regulations intended to promote participation in PA and sport. ${ }^{24,25}$ They are, however, more related to formal sport than to PA in general. The Sport School Norm, for example, established sport activity as mandatory in all schools. Broadly speaking, levels of PA and practice of sport have not been impaired by lack of regulations.

There are 3 main policy documents for the promotion of PA among children and adolescents: (1) the General Regulation for Physical Activity and Sports, (2) Strategic Plan for Education to 2012 to 2016, and (3) Decree Law for Scholar Sports Regulation. ${ }^{24,26,27}$ Although the policies have not created all of the necessary conditions, they did establish an official position that recognizes PA as an important factor in public health and youth development. A grade of $\mathrm{C}$ was thus assigned to this indicator.

\section{Limitations}

A major weakness of the 2014 Mozambique Report Card was the general lack of information to inform the grades for each indicator. In the absence of robust data, grades were assigned based on regional studies and expert consensus. Most of the objective data came from scientific papers designed to study relationships and not to assess the Mozambican population as a whole. There is a clear and urgent need for investment in research to provide an understanding of PA of children and adolescents in Mozambique. With rapid urbanization, it is also important to evaluate the effects these changes on the health 
and PA behaviors of city dwelling young people. Such information is also essential to inform the development of intervention efforts in the near future. The situation in Mozambique thus calls for caution in interpreting and evaluating the assigned grades in this first report card. Nevertheless, the assessment of conditions related to PA was useful and constituted an important reference that will serve as a baseline for comparison for future Mozambique Report Cards on Physical Activity of Children and Adolescents.

\section{Conclusion}

Although the available information has major limitations, PA behaviors of children and adolescents are positively influenced by the rural environment, due mainly due to participation in subsistence activities, outdoor play and absence of motorized transport. At the same time, children and adolescents residing in the cities are experiencing a decline in PA habits due to minimal planning for active transport and play associated rapid urbanization. It is expected that urban populations in many areas of the world will increase exponentially in the coming years, ${ }^{28}$ it seems likely that opportunities for and habits of PA will decline. The need for public policy, specifically regarding urban planning and population well-being, is essential.

\section{References}

1. The Word Bank. Mozambique [cited 2013 29-12]. Available from: http://data.worldbank.org/country/mozambique

2. United Nations. HDI Indicators by Country 20122012 [cited 2013 29-12]. Available from: https://data.undp.org/dataset/HDI-Indicatorsby-Country-2012/nz26-sffk?

3. World Health Organization. Global Health Observatory Data Repository - Life expectancy by country [cited 2013 29-12]. Available from: http://apps.who.int/gho/data/node.main.688?lang=en

4. World Health Organization. Data repository-Child mortality levels: number of deaths (thousands) by country [cited 2013 29-12]. Available from: http://apps.who.int/gho/data/node.main.ChildMort-1 ?lang=en

5. UNICEF. Mozambique - Statistics [cited 2013 29-12]. Available from: http://www.unicef.org/infobycountry/mozambique_statistics.html

6. Prista A, Marques AT, Maia JAR. Relationship between physical activity, socioeconomic status and physical fitness of 8-15 year old youth from Mozambique. Am J Hum Biol. 1997;4(9):449-457. doi:10.1002/ (SICI)1520-6300(1997)9:4<449::AID-AJHB4>3.0.CO;2-R

7. Nhantumbo L, Maia J, Saranga S, Prista A. Physical activity among children and adolescents in a rural community in Mozambique: effects of age, sex, and nutritional status]. Revista Panamerican de Salud Publica. 2008;23(3):171-8. Portuguese. PubMed PMID: 18397583.

8. Damasceno A, Azevedo A, Silva-Matos C, Prista A, Diogo D, Lunet $\mathrm{N}$. Hypertension prevalence, awareness, treatment, and control in Mozambique: urban/rural gap during epidemiological transition. Hypertension. 2009;54(1):77-83. Epub 2009 May 26.

9. African Health Observatory, World Health Organization. Available from: http://www.aho.afro.who.int/profiles_information/index.php/ Mozambique:Index/pt. Accessed on January 10, 2014.

10. Colley RC, Brownrigg M, Tremblay MS. A model of knowledge translation in health: the Active Healthy Kids Canada Report Card on Physical Activity for Children and Youth. Health Promot Pract. 2012;13(3):320-330. PubMed doi:10.1177/1524839911432929
11. Ministério da Saúde (MISAU), Instituto Nacional de Estatística (INE) e ICF International (ICFI). Moçambique Inquérito Demográfico e de Saúde 2011. Calverton, Maryland, USA: MISAU, INE e ICFI.

12. Prista A, Maia AJR, Marques AT. An empirical validation of an instrument to measure habitual physical activity in students from Maputo, Mozambique. Am J Hum Biol. 2000;12(4):437-446. PubMed doi:10.1002/1520-6300(200007/08)12:4<437::AIDAJHB2>3.0.CO;2-S

13. Padrão P, Damasceno A, Silva-Matos C, Prista A, Lunet N. Physical activity patterns in Mozambique: urban/rural differences during epidemiological transition. Preventive Medicine. 2012;55(5):444-9.

14. Santos FK, Gomes TNQF, Damasceno A, Prista A, Eisenmann J, Maia J. Physical activity, fitness, and the metabolic syndrome in rural youth from Mozambique. Ann Hum Biol. 2013;40(1):15-22.

15. Lopes V, Prista A, Nhantumbo L, et al. Níveis e padrões de actividade física de crianças e jovens de Calanga $\bigotimes$ da simples descrição à sua relevância em termos funcionais. In: O desafio de Calanga - do lugar e das pessoas à aventura da ciência. A. Prista, L. Nhantumbo, S. Saranga, J. Maia (eds). FADE-UP, FEFD-UP. Maputo; 2010.

16. Saranga S, Prista A, Nhantumbo L, Manasse S, Seabra A, Maia J. Alterações no padrão de actividade física em função da urbanização e determinantes socio-culturais: um estudo em crianças e jovens de Maputo (Moçambique). Revista Brasileira de Ciência e Movimento. 2008;16(2):17-24.

17. Prista A, Magaia S, Silva-Matos C, Damasceno A. Saúde, estilo de vida e urbanização em Moçambique: problemas e perspectivas. Revista Moçambicana de Saúde Publica. Revista Moçambicana de Ciências de Saúde, in press.

18. INADE. (2012). Relatório dos Jogos Tradicionais realizado na Província de Niassa, 2012. Maputo.

19. Nhantumbo L, Saranga S, Seabra A, Maia J, Prista A. Aptidão física e actividade física em populações africanas: uma revisão da literatura. Revista Portuguesa de Ciências do Desporto. 2006;6(3):373-400.

20. Prista A, Maia J, Nhantumbo L, et al. (2010) Variabilidade biológica humana em Moçambique - a visão, as pessoas e a estrutura de um projecto nacional de impacto internacional. In: O desafio de calangado lugar e das pessoas à aventura da ciência. A. Prista, L. Nhantumbo, S. Saranga, J. Maia (eds). FADE-UP, FEFD-UP. Maputo.

21. INDE/MINED. Plano Curricular do Ensino Básico. Maputo: Moçambique; 2003.

22. INDE/MEC. Plano Curricular do Ensino Secundário Geral. Maputo: Moçambique; 2006.

23. Prista A. Sedentarismo, urbanização e transição epidemiológica. Revista Cientifica da UEM. Series Ciências Biomédicas e Saúde. 2012;1(0):28-38.

24. Diploma Ministerial n ${ }^{\circ} 24 / 99$ de 24 de Março aprova o Regulamento do desporto escolar

25. Southern African Development Community (SADC). Resolução 1/2002 de 14 de Fevereiro, ratifica o Protocolo da SADC sobre a cultura, informação e o Desporto.

26. MINED. Regulamento Geral de Educação Física e Desporto. Maputo, Mozambique. 1994.

27. MINED. Plano Estratégico do Sector da Educação 2012-2016. (Draft). Maputo: Moçambique; 2011.

28. UNFPA. State of world population 2007: Unleashing the Potential of Urban Growth. Available on: http://www.unfpa.org/webdav/ site/global/shared/documents/publications/2007/695_filename_ sowp2007_eng.pdf 